\title{
Lead Transport in Soils Amended with Municipal Solid Waste Ash
}

\author{
Saud Al-Oud, Adel Ghoneim* \\ Department of Soil Sciences, Faculty of Food and Agriculture Sciences, King Saud University \\ P.O. Box 2460, Riyadh 11451, Saudi Arabia
}

Received: 4 May 2017

Accepted: 23 July 2017

\begin{abstract}
Municipal solid waste (MSW) is one of the major environmental problems in the Kingdom of Saudi Arabia (KSA). Many efforts have been made to reduce and recover MSW, but land disposal is still the most popular option. The current research aims to investigate the effects of municipal solid waste ash (MSWA) application rates on the mobility of $\mathrm{Pb}$ by 2 soils with their different physical and chemical properties. The soil was amended with MSWA at the rate of $0,1,2,3$, and $5 \%(\mathrm{w} / \mathrm{w})$. Pb adsorption experiments were carried out by mixing $1.0 \mathrm{~g}$ of samples with initial $\mathrm{Pb}$ concentration varying from 0 to $300 \mathrm{mg} \mathrm{L}^{-1}$. The results indicated that distribution coefficient $\left(\mathrm{K}_{\mathrm{d}}\right)$ values of $\mathrm{Pb}^{2+}$ on sandy loam soil were higher than those on sandy loam soil. The application rate of 5\% MSWA to loamy sand and sandy loam soils resulted in increases of $\mathrm{K}_{\mathrm{d}}$ values by $36.6 \%$ and $29.0 \%$ more than the control soil $(0 \%)$. MSWA amendment is most effective in reducing $\mathrm{Pb}$ mobility in the studied soils. The results suggest that MSWA could be used as a low-cost adsorbent for $\mathrm{Pb}^{2+}$ of contaminated soils.
\end{abstract}

Keywords: municipal solid waste ash, soils, distribution coefficient, $\mathrm{Pb}$ adsorption

\section{Introduction}

The volume of municipal solid waste (MSW) produced in the world is increasing annually, and disposing of such wastes is a growing problem. MSW generation has become an important issue in recent years due to the uncontrolled growth of the urban population and industrialization in Riyadh, Kingdom of Saudi Arabia (KSA). Total MSW production has increased to more than 12 million tons year ${ }^{-1}$ and projections show that MSW production has exceeded 20 million tons per annum by 2015 and the per capita MSW production in KSA varied from 1.50 to $1.80 \mathrm{~kg}$ person ${ }^{-1}$ day $^{-1}[1]$. The heavy metals

*e-mail: aghoneim@ksu.edu.sa
$\mathrm{Cr}, \mathrm{Cu}, \mathrm{Hg}, \mathrm{Ni}, \mathrm{Cd}, \mathrm{Zn}$, and $\mathrm{Pb}$ are the most commonly found in municipal solid waste ash (MSWA), and $\mathrm{Pb}$ usually exists in the largest amounts [2]. These metals are harmful to the environment if there are no treatments. The environmental and technical problems have discouraged the reuse of MSWA. Even though pre-treatment increases the total cost, the treatment process enables the MSWA to be reused. Any one of the applications would be a great contribution to minimizing the waste and providing an alternative to landfill. Many of the applications of MSWA are still under investigation. The common method of MSWA disposal in KSA is dumping it into soils, because it is the cheapest way. The contaminated soils by MSWA application have the potential for groundwater pollution - especially with heavy metals [3]. Moreover, leachate from MSWA dumpsites affect the physical and chemical 
properties of the soils [4-5]. MSWA has received special attention for removal of heavy metals from soils and wastewater [6-7].

Contamination of soils by $\mathrm{Pb}$ has increased dramatically due to anthropogenic activity in recent decades. The presence of $\mathrm{Pb}$ in the environment is of a major concern because of its toxicity, bio-accumulating tendency, and threat to human health. The major sources of $\mathrm{Pb}$ are exhaust gases of petrol engines, pesticides, fertilizer impurities, emissions from mining and smelting operations, and the combustion of fossil fuels [8-10]. Clay content, soil $\mathrm{pH}$, and $\mathrm{Fe}$ and $\mathrm{Mn}$ oxides are the most important factors affecting the mobility of $\mathrm{Pb}$ in soils. Although the leaching of $\mathrm{Pb}$ into groundwater often occurs at low $\mathrm{pH}$, at higher $\mathrm{pH} \mathrm{Pb}$ may precipitate as $\mathrm{Pb}(\mathrm{OH})_{2}$ with low solubility [11]. The stabilization of $\mathrm{Pb}$-contaminated soils using immobilizing amendments such as MWSA is a kind of remediation procedure practical for reducing $\mathrm{Pb}$ mobility in soils [12]. Stabilization of $\mathrm{Pb}$ in soils can be achieved by $\mathrm{Pb}$ adsorption, complexion, and precipitating of $\mathrm{Pb}$. The transport and distribution of $\mathrm{Pb}$ through soils is important because of the possibility of contamination of both surface and ground water [13]. The dramatic growth in urbanization and population in Riyadh has brought some environmental challenges that need to be efficiently dealt with. One of these challenges is finding the proper management of hugely produced MSWA. Recycling of MSWA via landfill is a possible option of its management that has recently received more attention, although the

Table 1. Selected physical and chemical properties of soils.

\begin{tabular}{|c|c|c|}
\hline \multirow{2}{*}{ Parameters } & \multicolumn{2}{|c|}{ Soils } \\
\hline & Loamy Sand & Sandy Loam \\
\hline Sand (\%) & 85.5 & 73.5 \\
\hline Silt (\%) & 8.00 & 19.0 \\
\hline Clay (\%) & 6.48 & 7.48 \\
\hline $\mathrm{CEC}\left(\mathrm{cmol} \mathrm{kg}^{-1}\right)$ & 4.85 & 6.46 \\
\hline $\mathrm{CaCO}_{3}(\%)$ & 23.2 & 34.3 \\
\hline OM (\%) & 1.04 & 1.07 \\
\hline pH (soil paste) & 7.80 & 8.07 \\
\hline $\mathrm{EC}\left(\mathrm{dS} \mathrm{m} \mathrm{m}^{-1}\right)$ & 1.0 & 1.6 \\
\hline \multicolumn{3}{|c|}{ Cations and anions (meq L ${ }^{-1}$ ) } \\
\hline $\mathrm{Ca}^{2+}$ & 4.31 & 8.51 \\
\hline $\mathrm{Mg}^{2+}$ & 3.42 & 4.10 \\
\hline $\mathrm{Na}^{+}$ & 1.13 & 2.05 \\
\hline $\mathrm{K}^{+}$ & 0.69 & 0.72 \\
\hline $\mathrm{HCO}_{3}^{-}$ & 4.25 & 7.56 \\
\hline $\mathrm{Cl}^{-}$ & 1.91 & 3.64 \\
\hline $\mathrm{SO}_{4}^{2-}$ & 3.82 & 4.50 \\
\hline
\end{tabular}

impact of MSWA application on $\mathrm{Pb}$ transport into soils is not widely studied under arid soil conditions. The MSWA which has unique chemical characteristics may exert effects on $\mathrm{Pb}$ mobility and distribution in soils. However, there is limited information addressing the fate of $\mathrm{Pb}$ added by MSWA dumpsites into soils in arid and semiarid regions. The objective of this study was to examine the effects of MSWA application rates on adsorption and mobility of $\mathrm{Pb}$ by two soils with their different physical and chemical properties.

\section{Material and Methods}

\section{Soil Samples}

Two representative surface soil samples $(0-30 \mathrm{~cm})$

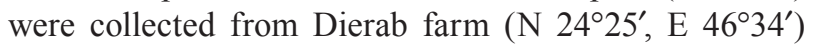
$40 \mathrm{~km}$ south west of Riyadh. The soil sample was airdried and sieved through a 2-mm mesh. Soil texture, $\mathrm{pH}$, electrical conductivity (EC), $\mathrm{CaCO}_{3} \%$, cation exchange capacity (CCE), and organic matter (OM) were determined using the standard methods described in [14]. The related chemical properties of the soils are presented in Table 1.

\section{MSW Samples and Chemical Analysis}

MSW samples were collected from four different dumping sites of Hail, KSA (N $27^{\circ} 30^{\prime}$, E $41^{\circ} 43^{\prime}$ ). The MSW was incinerated in a kiln that allowed for the generated gases to pass through a water bath and avoid air pollution. The MSWA was then screened through a $0.30 \mathrm{~mm}$ sieve to remove un-burnt MSW, ceramics, and broken glasses. The ash was further ground using a micromilling machine for particle sizes less than $0.063 \mathrm{~mm}$. The resultant ash was analysed for total $\mathrm{CaCO}_{3}$ content using the method applied [15]. The CEC was determined using sodium acetate $(\mathrm{pH} 8.20)$ according to the method described in [16]. Total $\mathrm{Cd}, \mathrm{Pb}, \mathrm{Cu}$, and $\mathrm{Zn}$ content were digested by a concentrated mixture of $\mathrm{HNO}_{3}-\mathrm{HClO}_{4}$ acids and measured using induction-coupled plasmamass spectrometry (ICP-MS, Perkin Elmer, USA). The chemical properties of MSWA are presented in Table 2.

\section{Particle Size Analysis of MSWA}

The particle size distribution analysis of the MSW ash samples was determined using the laser diffraction spectrometry method using a laser diffracto-meter. The analysis was performed in triplicate of each sub-sample with water as a dispersing agent in the wet method and air as a dispersing agent in the dry method. The dried MSWA samples were placed in the laser diffraction machine and subjected to dispersion energy in the presence of a suspension medium. The ash particle sizes were determined from the intensity of the scattered light by the particles in suspension due to their different refractive indices. 
Table 2. Chemical characterization of MSWA.

\begin{tabular}{|c|c|}
\hline Parameter & Value \\
\hline $\mathrm{SiO}_{2}$ & $26.0 \%$ \\
\hline $\mathrm{Al}_{2} \mathrm{O}_{3}$ & $27.3 \%$ \\
\hline $\mathrm{CaO}$ & $31.1 \%$ \\
\hline $\mathrm{Fe}_{2} \mathrm{O}_{3}$ & $2.50 \%$ \\
\hline $\mathrm{MgO}$ & $3.50 \%$ \\
\hline $\mathrm{K}_{2} \mathrm{O}$ & $4.20 \%$ \\
\hline $\mathrm{Na}_{2} \mathrm{O}$ & $2.50 \%$ \\
\hline $\mathrm{P}_{2} \mathrm{O}_{5}$ & $1.50 \%$ \\
\hline $\mathrm{TiO}_{2}$ & $1.40 \%$ \\
\hline $\mathrm{CEC}^{2}$ & $8.10 \mathrm{cmol} \mathrm{kg}-1$ \\
\hline $\mathrm{OM}^{-1}$ & $20.0 \%$ \\
\hline $\mathrm{CaCO}_{3}$ & $11.8 \%$ \\
\hline $\mathrm{pH}$ & 12.0 \\
\hline \multicolumn{2}{|c|}{ Particle size distribution } \\
\hline $2.0-1.0 \mathrm{~mm}$ & $0.40 \%$ \\
\hline $1.0-0.50 \mathrm{~mm}$ & $36.7 \%$ \\
\hline $0.50-0.25 \mathrm{~mm}$ & $30.5 \%$ \\
\hline $0.25-0.125 \mathrm{~mm}$ & $20.6 \%$ \\
\hline $0.125-0.063 \mathrm{~mm}$ & $7.88 \%$ \\
\hline Less than $0.063 \mathrm{~mm}$ & $3.92 \%$ \\
\hline & \\
\hline & \\
\hline
\end{tabular}

\section{Adsorption Experiment}

Soil samples were mixed with MSWA @ 0, 1, 2, 3, and $5 \%(\mathrm{w} / \mathrm{w})$ with particle sizes less than $0.063 \mathrm{~mm}$. The adsorption experiment was carried out by mixing $2.0 \mathrm{~g}$ of soils-MSWA amended with $20 \mathrm{~mL}$ of $\mathrm{PbCl}_{2}$ solution at different concentrations varying from 0 to $300 \mathrm{mg} \mathrm{Pb} \mathrm{L}^{-1}$. The mixture was shaken for 24 hours at room temperature and then centrifuged at $5,000 \mathrm{rpm}$ for 20 minutes. The $\mathrm{Pb}$ concentration in the supernatant was measured using (ICP-MS, Perkin Elmer, USA). The amount of $\mathrm{Pb}$ adsorbed on soils was estimated according to the following equation:

$$
\mathrm{X} / \mathrm{m}=\left(\mathrm{C}_{\mathrm{i}}-\mathrm{C}_{\mathrm{f}}\right) \mathrm{V} / \mathrm{W}
$$

...where $\mathrm{X} / \mathrm{m}$ is the amount of the $\mathrm{Pb}^{2+}$ adsorbed on soils $\left(\mathrm{mg} \mathrm{kg}^{-1}\right), \mathrm{C}_{\mathrm{i}}$ is the initial $\mathrm{Pb}$ concentration $\left(\mathrm{mg} \mathrm{L}^{-1}\right)$, $\mathrm{C}_{\mathrm{f}}$ is the final $\mathrm{Pb}$ concentration $\left(\mathrm{mg} \mathrm{L}^{-1}\right), \mathrm{V}$ is the volume of solution used $(\mathrm{mL})$, and $\mathrm{W}$ is the weight of soil sample (g).

The $K_{\mathrm{d}}$ values were estimated according to [17]:

$$
\mathrm{K}_{\mathrm{d}}=\mathrm{S} / \mathrm{C}
$$

...where $\mathrm{K}_{\mathrm{d}}$ is the distribution coefficient $\left(\mathrm{cm}^{-3} \mathrm{~g}^{-1}\right), \mathrm{S}$ is adsorbed $\mathrm{Pb}\left(\mathrm{mg} \mathrm{g}^{-1}\right)$ and $\mathrm{C}$ is equilibrium $\mathrm{Pb}$ concentration (mg L-1).

\section{Results and Discussion}

\section{Characterization of Soils and MSWA}

The summary of the physico-chemical properties of soil (CEC, $\mathrm{pH}, \mathrm{EC}$, particle size distribution, and $\mathrm{OM}$ ) are presented in Table 1. Soil pH, EC, OM, and clay content were consistently least variable, while sand, silt, CEC, and $\mathrm{CaCO}_{3}$ were the highest. The texture of soils is dominated mainly by sand fraction, which ranged from $73.5 \%$ to $85.5 \%$. The silt fraction ranged from $8 \%$ in loamy soil to $19 \%$ in sandy soil. The soil $\mathrm{pH}$ is alkaline with an average of 7.94. The EC value recorded for loamy sand soil and sandy soil belong to normal classes. The soils had a high $\mathrm{CaCO}_{3}$ content ranging from $23.2 \%$ to $34.3 \%$. The soils were low in OM content (1.0-1.6\%) and CEC values (4.85-6.46 $\left.\mathrm{cmol} \mathrm{kg} \mathrm{kg}^{-1}\right)$. The results of soil properties indicated that the soil $\mathrm{pH}$ is alkaline and $\mathrm{EC}$ values are non-saline. The soils have high $\mathrm{CaCO}_{3}$ content and are low in OM and CEC values.

The mechanical properties of MSWA are expressed in terms of particle sizes. As shown in Table 2, the MSWA ranged from very fine to very coarse sand sizes. The coarse particles of size range from 1.0 to $2.0 \mathrm{~mm}$ and represent the largest component $(36.76 \%)$ of the MSWA. The summary of the values that determined chemical properties of MSWA are presented in Table 2. The predominant chemical constituents of MSWA are aluminates, silicates, and lime. The oxides of $\mathrm{Ca}, \mathrm{Al}$, and $\mathrm{Si}$ content were higher, while oxides of $\mathrm{Fe}, \mathrm{K}, \mathrm{Na}, \mathrm{P}$, and Ti were moderately variable, and $\mathrm{CaO}$ was the most abundant compound (31.1\%). MSWA had a lower CEC and $\mathrm{CaCO}_{3}$ values and higher OM content $(20.0 \%)$. The physicochemical properties of MSW primarily depend on the nature of the parent MSW composition [18]. Alkalinity is an important MSW characteristic and results from the presence of $\mathrm{Ca}, \mathrm{Na}, \mathrm{Mg}$, and $\mathrm{OH}$, along with certain other trace metals [19].

\section{Adsorption of $\mathrm{Pb}^{2+}$}

The adsorption data for $\mathrm{Pb}^{2+}$ on the two soils as well as mixtures of these soils with MSWA are presented in Tables 3 and 4. Amounts of adsorbed $\mathrm{Pb}^{2+}$ on soils increased with increasing initial $\mathrm{Pb}$ concentration from 25 to $300 \mathrm{mg} \mathrm{L}^{-1}$. Loamy sand soil adsorbed much more $\mathrm{Pb}^{2+}$ than sandy loam soil. The application of MSWA has led to decreases in the ability of soils to absorb $\mathrm{Pb}^{2+}$. With increasing application rates of MSWA, the amounts of $\mathrm{Pb}^{2+}$ decreased on both soils. Soils with high $\mathrm{pH}$ and $\mathrm{CEC}$ values adsorbed more $\mathrm{Pb}^{2+}$ than those with lower $\mathrm{pH}$ and $\mathrm{CEC}$ values [20-21]. The loam sandy soil was more likely to adsorb $\mathrm{Pb}^{2+}$ than the sandy loam soil. The results give a clear idea of the adsorption of $\mathrm{Pb}^{2+}$ 
Table 3. Adsorption of $\mathrm{Pb}^{2+}$ on loamy sand soil mixed with different application rates of MSWA.

\begin{tabular}{|c|c|c|c|c|c|c|c|c|c|c|}
\hline \multirow{3}{*}{$\begin{array}{c}\mathrm{C}_{0} \\
\left(\mathrm{mg} \mathrm{L}^{-1}\right)\end{array}$} & \multicolumn{10}{|c|}{ Application rate of MSWA } \\
\hline & \multicolumn{2}{|c|}{$0 \%$} & \multicolumn{2}{|c|}{$1 \%$} & \multicolumn{2}{|c|}{$2 \%$} & \multicolumn{2}{|c|}{$3 \%$} & \multicolumn{2}{|c|}{$5 \%$} \\
\hline & $\begin{array}{c}\mathrm{C}_{\mathrm{e}} \\
\left(\mathrm{mg} \mathrm{L}^{-1}\right)\end{array}$ & $\begin{array}{c}\mathrm{S} \\
\left(\mathrm{mg} \mathrm{g}^{-1}\right)\end{array}$ & $\begin{array}{c}\mathrm{C}_{\mathrm{e}} \\
\left(\mathrm{mg} \mathrm{L}^{-1}\right)\end{array}$ & $\begin{array}{c}\mathrm{S} \\
\left(\mathrm{mg} \mathrm{g}^{-1}\right)\end{array}$ & $\begin{array}{c}\mathrm{C}_{\mathrm{e}} \\
\left(\mathrm{mg} \mathrm{L}^{-1}\right)\end{array}$ & $\begin{array}{c}\mathrm{S} \\
\left(\mathrm{mg} \mathrm{g}^{-1}\right)\end{array}$ & $\begin{array}{c}\mathrm{C}_{\mathrm{e}} \\
\left(\mathrm{mg} \mathrm{L}^{-1}\right)\end{array}$ & $\begin{array}{c}\mathrm{S} \\
\left(\mathrm{mg} \mathrm{g}^{-1}\right)\end{array}$ & $\begin{array}{c}\mathrm{C}_{\mathrm{e}} \\
\left(\mathrm{mg} \mathrm{L}^{-1}\right)\end{array}$ & $\begin{array}{c}\mathrm{S} \\
\left(\mathrm{mg} \mathrm{g}^{-1}\right)\end{array}$ \\
\hline 25 & 0.0047 & 4.70 & 0.005 & 4.50 & 0.004 & 4.100 & 0.004 & 3.850 & 0.004 & 3.50 \\
\hline 50 & 0.0097 & 9.70 & 0.009 & 9.10 & 0.008 & 8.300 & 0.008 & 8.050 & 0.007 & 7.10 \\
\hline 100 & 0.0195 & 19.5 & 0.019 & 18.5 & 0.017 & 17.0 & 0.016 & 16.1 & 0.015 & 14.8 \\
\hline 150 & 0.0292 & 29.2 & 0.027 & 27.3 & 0.025 & 25.2 & 0.024 & 24.2 & 0.022 & 22.3 \\
\hline 200 & 0.0385 & 38.5 & 0.036 & 36.2 & 0.034 & 33.7 & 0.032 & 32.4 & 0.029 & 29.1 \\
\hline 250 & 0.0481 & 48.1 & 0.046 & 45.5 & 0.042 & 42.3 & 0.040 & 40.4 & 0.037 & 36.9 \\
\hline 300 & 0.0575 & 57.5 & 0.055 & 54.7 & 0.051 & 51.0 & 0.049 & 48.7 & 0.045 & 45.2 \\
\hline$K_{d}$ & \multicolumn{2}{|c|}{41.95} & \multicolumn{2}{|c|}{44.92} & \multicolumn{2}{|c|}{49.08} & \multicolumn{2}{|c|}{51.76} & \multicolumn{2}{|c|}{$\mathbf{5 7 . 3 3}$} \\
\hline $\mathrm{R}^{2}$ & \multicolumn{2}{|c|}{0.999} & \multicolumn{2}{|c|}{0.999} & \multicolumn{2}{|c|}{0.999} & \multicolumn{2}{|c|}{0.999} & \multicolumn{2}{|c|}{0.999} \\
\hline
\end{tabular}

$\mathrm{C}_{0}$ : initial $\mathrm{Pb}$ concentration; $\mathrm{C}_{\mathrm{e}}$ : equilibrium $\mathrm{Pb}$ concentration; $\mathrm{S}$ : adsorbed $\mathrm{Pb} ; \mathrm{K}_{\mathrm{d}}$ : Distribution coefficient $\left(\mathrm{cm}^{3} \mathrm{~g}^{-1}\right)$.

on loamy sand soil and sandy loam amended with different rates of MSWA ranging from 1.0 to $5.0 \%$. Soils amended with MSWA may change the soil's ability for $\mathrm{Pb}^{2+}$ adsorption because of increases in the $\mathrm{pH}$ of soils. Soil $\mathrm{pH}$ plays a major role in the adsorption of $\mathrm{Pb}$ because it directly controls the solubility of $\mathrm{Pb}(\mathrm{OH})_{2}$. In addition, soil $\mathrm{pH}$ affects net surface charges of soils [22-23]. Although the mobility of $\mathrm{Pb}$ in soils is controlled by adsorption and desorption characteristics of soil, the mobility of $\mathrm{Pb}$ depends not only on its distribution among several species, but also on diffusion coefficients [24]. [25] studied the effect of residence time on $\mathrm{Pb}$ adsorption on hydrous Fe oxides and they reported that residence time had significant effect on the amount of $\mathrm{Pb}$, which could be ascribed to the strong $\mathrm{Pb}$ into soil complexes. Reduction of $\mathrm{Pb}$ mobility by MSWA application may be two mechanisms: increasing $\mathrm{pH}$ and higher specific surface area, which causes the precipitation of insoluble phases and promotes $\mathrm{Pb}$ adsorption via surface complexation [26-27].

\section{Distribution Coefficient}

The calculated $\mathrm{K}_{\mathrm{d}}$ values are presented in Tables 3 and 4. The results indicate that $\mathrm{Pb}^{2+}$ was distributed in soil solution and the adsorbed phase, in which a great portion accounted for the adsorbed phase. Lower $\mathrm{K}_{\mathrm{d}}$ values indicate that most of the $\mathrm{Pb}^{2+}$ present in the soil system remain in the solution and will be available for transporting into soils, whereas higher values as reported

Table 4. Adsorption of $\mathrm{Pb}^{2+}$ on sandy loam soil mixed with different application rates of MSWA.

\begin{tabular}{|c|c|c|c|c|c|c|c|c|c|c|}
\hline \multirow{3}{*}{$\begin{array}{c}\mathrm{C}_{0} \\
\left(\mathrm{mg} \mathrm{L}^{-1}\right)\end{array}$} & \multicolumn{10}{|c|}{ Application rate of MSWA } \\
\hline & \multicolumn{2}{|c|}{$0 \%$} & \multicolumn{2}{|c|}{$1 \%$} & \multicolumn{2}{|c|}{$2 \%$} & \multicolumn{2}{|c|}{$3 \%$} & \multicolumn{2}{|c|}{$5 \%$} \\
\hline & $\begin{array}{c}\mathrm{C}_{\mathrm{e}} \\
\left(\mathrm{mg} \mathrm{L}^{-1}\right)\end{array}$ & $\begin{array}{c}\mathrm{S} \\
\left(\mathrm{mg} \mathrm{g}^{-1}\right)\end{array}$ & $\begin{array}{c}\mathrm{C}_{\mathrm{e}} \\
\left(\mathrm{mg} \mathrm{L}^{-1}\right)\end{array}$ & $\begin{array}{c}\mathrm{S} \\
\left(\mathrm{mg} \mathrm{g}^{-1}\right)\end{array}$ & $\begin{array}{c}\mathrm{C}_{\mathrm{e}} \\
\left(\mathrm{mg} \mathrm{L}^{-1}\right)\end{array}$ & $\begin{array}{c}\mathrm{S} \\
\left(\mathrm{mg} \mathrm{g}^{-1}\right)\end{array}$ & $\begin{array}{c}\mathrm{C}_{\mathrm{e}} \\
\left(\mathrm{mg} \mathrm{L}^{-1}\right)\end{array}$ & $\begin{array}{c}\mathrm{S} \\
\left(\mathrm{mg} \mathrm{g}^{-1}\right)\end{array}$ & $\begin{array}{c}\mathrm{C}_{\mathrm{e}} \\
\left(\mathrm{mg} \mathrm{L}^{-1}\right)\end{array}$ & $\begin{array}{c}\mathrm{S} \\
\left(\mathrm{mg} \mathrm{g}^{-1}\right)\end{array}$ \\
\hline 25 & 0.0040 & 4.00 & 0.004 & 3.80 & 0.003 & 3.45 & 0.003 & 3.30 & 0.003 & 3.10 \\
\hline 50 & 0.0079 & 7.90 & 0.008 & 7.70 & 0.007 & 7.10 & 0.007 & 6.70 & 0.006 & 6.30 \\
\hline 100 & 0.0161 & 16.0 & 0.015 & 15.4 & 0.014 & 14.1 & 0.014 & 13.9 & 0.013 & 12.7 \\
\hline 150 & 0.0241 & 24.1 & 0.023 & 23.3 & 0.022 & 21.9 & 0.020 & 20.1 & 0.020 & 19.6 \\
\hline 200 & 0.0324 & 32.4 & 0.031 & 31.1 & 0.029 & 28.6 & 0.028 & 27.6 & 0.026 & 26.1 \\
\hline 250 & 0.0406 & 40.6 & 0.039 & 39.0 & 0.036 & 36.1 & 0.034 & 34.1 & 0.033 & 32.6 \\
\hline 300 & 0.0481 & 48.1 & 0.047 & 46.7 & 0.043 & 43.2 & 0.041 & 41.2 & 0.039 & 38.5 \\
\hline $\mathbf{K}_{\mathbf{d}}$ & \multicolumn{2}{|c|}{52.04} & \multicolumn{2}{|c|}{54.26} & \multicolumn{2}{|c|}{59.41} & \multicolumn{2}{|c|}{62.95} & \multicolumn{2}{|c|}{67.15} \\
\hline $\mathrm{R}^{2}$ & \multicolumn{2}{|c|}{0.999} & \multicolumn{2}{|c|}{0.999} & \multicolumn{2}{|c|}{0.999} & \multicolumn{2}{|c|}{0.999} & \multicolumn{2}{|c|}{0.999} \\
\hline
\end{tabular}

$\mathrm{C}_{0}$ : initial $\mathrm{Pb}$ concentration; $\mathrm{C}_{\mathrm{e}}$ : equilibrium $\mathrm{Pb}$ concentration; $\mathrm{S}$ : adsorbed $\mathrm{Pb} ; \mathrm{K}_{\mathrm{d}}$ : Distribution coefficient $\left(\mathrm{cm}^{3} \mathrm{~g}^{-1}\right)$. 
here indicate lower mobility and stabilization of $\mathrm{Pb}^{2+}$ and sub sub-sequentially higher retention in the soils [28]. The application of 5\% MSWA to soils increased $\mathrm{K}_{\mathrm{d}}$ values to $36.6 \%$ and $29.0 \%$ more than the control $(0 \%)$. The results indicated that $\mathrm{K}_{\mathrm{d}}$ values were significantly correlated with MSWA application rates, with $\mathrm{R}^{2}$ value ranging from 0.974 to 0.993 (Fig. 1). In a previous study [29], $\mathrm{Pb}$ transport was studied in soil amended with different rates of MSWI by applying $\mathrm{Pb}$ solution of $150 \mathrm{mg} \mathrm{\textrm {L } ^ { - }}$ at the rate of $0.09 \mathrm{~cm} \mathrm{~min}^{-1}$ for loamy sand soil and $0.035 \mathrm{~cm} \mathrm{~min}^{-1}$ for sandy loam soil. The results indicated that extremely low $\mathrm{Pb}$ concentrations in the effluent solution were observed in leaching solution with time passing. In general, $\mathrm{Pb}^{2+}$ transport has been primarily found in the top $5 \mathrm{~cm}$ of the soil surface, which shows low mobility in the studied soils. This is usually attributed to differences in soil texture, sand, clay, and $\mathrm{CaCO}_{3}$ content.

$\mathrm{Pb}$ is strongly bound to $\mathrm{OM}$ and is rather immobile in soils except at extremely high concentrations [30]. The highest $\mathrm{K}_{d}$ values for $\mathrm{Pb}^{2+}$ were found at $5 \%$ application rate of MSWA, followed by $3 \%, 2 \%, 1 \%$, and control. MSWA shows higher adsorption capacity for $\mathrm{Pb}^{2+}$ because of its higher $\mathrm{pH}$ values [31]. The higher obtained $\mathrm{K}_{\mathrm{d}}$ values with lower $\mathrm{Pb}^{2+}$ concentrations were probably related to different soil properties. Otherwise, $\mathrm{Pb}^{2+}$ adsorption becomes unspecific at higher metal concentrations, resulting in lower $\mathrm{K}_{d}$ values [32]. The transport and distribution of $\mathrm{Pb}^{2+}$ in soils is directly related to amounts of $\mathrm{Pb}^{2+}$ adsorbed [33-34]. $\mathrm{Pb}$ is mainly adsorbed onto specific soil adsorption sites while with higher concentration; soils lose some of their ability to bind $\mathrm{Pb}^{2+}$ ions. Loamy sand soil has higher $\mathrm{K}_{\mathrm{d}}$ values than sandy loam soil at all rates of MSWA application (Tables 3 and 4). The results indicated that the $\mathrm{K}_{\mathrm{d}}$ values were influenced mainly by soil $\mathrm{pH}, \mathrm{CaCO}_{3} \%$, texture, and CEC values of soils. MSWA has the potential for $\mathrm{Pb}^{2+}$ removal from soils due to its chemical characterization (Table 2). The results suggest that $K_{d}$ values can be used for predicting $\mathrm{Pb}$ adsorption on soils. The $\mathrm{K}_{\mathrm{d}}$ constants

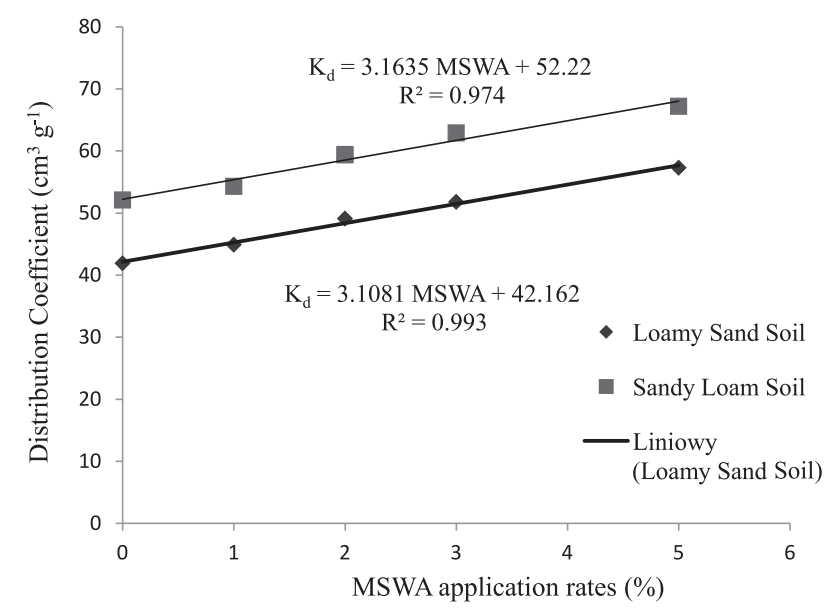

Fig. 1. Relationship between distribution coefficients of $\mathrm{Pb}$ and application rates of MSWA. of $\mathrm{Pb}^{2+}$ in soils can be related to its mobility and toxicity. The difference in $\mathrm{Pb}$ adsorption on soils has been reported [35-36]. Soils have the ability to immobilize $\mathrm{Pb}^{2+}$ mainly due to adsorption properties that may be affected by physical and chemical characterization of the soils, such as CEC, $\mathrm{pH}$, textures, and the properties of $\mathrm{Pb}$ [37-38].

\section{Conclusion}

The different properties of soils, such as CEC, $\mathrm{pH}$, and contents of silt and clay lead to the obvious differences in their ability for adsorption and mobility of $\mathrm{Pb}$. The addition of MSWA, which contains high content of OM, has increased the soil's ability for $\mathrm{Pb}^{2+}$ adsorption due to the increased $K_{d}$ values. The results indicate that MSWA has high power on $\mathrm{Pb}^{2+}$ retention in soils surface and thus may be used to remove $\mathrm{Pb}^{2+}$ from contaminated soils.

\section{Acknowledgements}

The authors appreciate and thank the College of Food and Agricultural Sciences, Research Center and Deanship of Scientific Research, King Saud University, Saudi Arabia, for financial support of this research study.

\section{References}

1. AL-MUTAIRI S.O., GHONEIM A.M., AL-MODAIHSH A.S., MAHJOUB M.O., REDA Y.A. Characterization and Composting of Municipal Solid Waste of Riyadh City, Saudi Arabia. Book Chapter In: Waste Management and Environment VII. WIT Transactions on Ecology and the Environment Editor(s) C.A. Brebbia, Wessex Institute of Technology, 83-292, WIT Press, Ashurst Lodge, Ashurst, Southmpton, UK, 2014.

2. CHOTPANTARAT S., ONG S.K., SUTTHIRAT S., OSATHAPHAN K. Competitive modelling of sorption and transport of $\mathrm{Pb}^{2+}, \mathrm{Ni}^{2+}, \mathrm{Mn}^{2+}$ and $\mathrm{Zn}^{2+}$ under binary and multi-metal systems in lateritic soil columns. Geoderma, 189-190, 278, 2012.

3. ZHANG H., LIN Y.H., ZHANG Z., ZHANG X., SHAW S.L., KNIPPING E.M., WEBER R.J., GOLD A., KAMENS R.M., SURRATT J.D. Secondary organic aerosol formation from methacrolein photooxidation: Roles of NOx level, relative humidity, and aerosol acidity. Environ. Chemistry, 9, 247, 2012.

4. SHI H.S., KAN L.L. Leaching behaviour of heavy metals from municipal solid wastes incineration (MSWI) fly ash used in concrete. J. Hazard. Materials, 164, 750, 2009.

5. UTPAL G., SHARMA H.P. Study of the impact of municipal solid waste dumping on soil quality in Guwahati city. Pollution research, 27, 327, 2008.

6. SARITHA V., SRIKANTH N.V., VUPPALA K., PRASHANTH I., AYESHA A. Soil Properties Governed by Municipal Solid waste-Contemporary and Enduring, Landmark Research Journals. Agriculture and Soil Sciences, 4, 42, 2014. 
7. RAJKUMAR N., SUBRAINANI T., ELANGO L. Groundwater contamination due to municipal solid waste disposal -AGIS- based study in Erode city. International J. of Environmental Sciences, 1, 5, 2010.

8. BISWIS A., RUSAL K., KUMAR S., BABU S.S., BHATTACHARYA A.K., CHAKRABARTI T. Studies on environmental quality in and around municipal solid waste dumpsite. Resource Conservation and Recycling, 55, 129, 2010.

9. TRIPATHI A., MISRA D.R. A study of physic-chemical properties and heavy metals in contaminated soils of municipal waste dumpsites of Allahabad, India. International J. of Environmental Sciences, 2, 2024, 2010.

10. BOSE S., Bhattacharyya A.K. Heavy metal accumulation in wheat plant grown in soil amended with industrial sludge. Chemosphere, 70, 1264, 2008.

11. ALLOWAY B. Heavy metals and metalloids as micronutrients for plants and animals. In, Alloway BJ (ed) Heavy metals in soils. Springer, The Netherlands, 209, 195, 2013.

12. CHAUDHARI S., TARE V. Removal and recovery of heavy metals from simulated wastewater using insoluble starch Xanthate process, Practice Periodical of Hazardous, Toxic, and Radioactive Waste Management, (C) ASCE, 170, 2008.

13. TOTH T., TOMAS J., LAZOR P., BAJCAN D., JOMOVA D. The Transfer of metals from contaminated soils into agricultural plants in high Tatars region. Czech J. Food Sci. 27, 390, 2009.

14. SPARKS D. Methods of Soil Analysis, Part 3. Chemical Methods, Soil Science Society of America Inc., Madison, Wisc, USA, 1996.

15. LOEPPERT, R.H, SUAREZ, D.L. Carbonate and gypsum p. 437-474. In D. L. Sparks et al. (Ed) Methods of Soil Analysis. Part3. SSSA Book Ser.5. SSSA, Madison, WI, 1996.

16. CHAPMAN H.D. Cation Exchange Capacity. In: Black, C.A., Ed., Methods of Soil Analysis, American Society of Agronomy, Madison, 891, 1965.

17. GOMES P.C, FONTES M.P, DA SILVA A.G, MENDONA E.S, NETTO R.A. Selectivity sequence and competitive adsorption of heavy metals by Brazilian soils. Soil Sci. Soc. Am. J., 65, 1115, 2001.

18. ALHAWAS M., ALWABEL M., GHONEIM A., ALFARRAJ A., SALLAM A. Removal of nickel from aqueous solution by low-cost clay adsorbents. Proceedings of the International Academy of Ecology and Environmental Sciences, 3, 160, 2013.

19. AL-OUD S.S, GHONEIM A.M, NADEEM M.A, AL HARBI S. Application efficiency of Clinoptilolite natural zeolite for $\mathrm{Pb}^{2+}$ and $\mathrm{Cu}^{2+}$ removal from Wastewater. Wulfenia J., 2, 317, 2015.

20. GHONEIM A.M., ELBASSIR O.I., MODAHISH A.S., MAHJOUB M.O. Compost production from olive tree pruning wastes enriched with phosphate rock. Compost Science \& Utilization, 25, 13, 2017.

21. FU F., WANG Q. Removal of heavy metal ions from waste waters: A review. J. of Environmental Management, 92, 407, 2011.

22. STEINNES E. Lead. P. 395-409. In: Alloway B. Heavy Metals in Soils: Trace metals and metalloids in soils and their bioavailability. $3^{\text {rd }}$. Springer Dordrecht Heidelberg New York London, 2013.
23. APPEL C., MA L.Q., RHUE R.D., REVE W. Sequential sorption of lead and cadmium in three tropical soils. Environ. Pollut. 155, 132, 2008.

24. SHAHEEN S.M. Sorption and lability of cadmium and lead in different soils from Egypt and Greece. Geoderma, 153, 61, 2009.

25. RASHAD M., DULTZ S., GUGGENBERGER G. Dissolved organic matter release and retention in an alkaline soil of the Nile River Delta in relation to surface charge and electrolyte type. Geoderma, 185, 385, 2010.

26. MAHMOUD E.K., GHONEIM A.M. Effect of polluted water on soil and plant contamination by heavy metals in El-Mahla El-Kobra, Egypt. Solid Earth 7, 703, 2016.

27. DECOCK C., LEE J., NECPALOVA M., PEREIRA E. I. P., TENDALL D.M., SIX, J. Mitigating $\mathrm{N}_{2} \mathrm{O}$ emissions from soil: from patching leaks to transformative action. Soil, $\mathbf{1}$, 687, 2015.

28. DONG J., YANG Q.W., SUN L.N., ZENG Q., LIU S.J., PAN J. Assessing the concentration and potential dietary risk of heavy metals in vegetables at a $\mathrm{Pb} / \mathrm{Zn}$ mine site, China. Environ. Earth Sci., 64, 1317, 2011.

29. AL-OUD S.S., GHONEIM A.M. Transport and distribution of $\mathrm{Pb}$ in soils treated with municipal solid waste incineration. J. of Agric. Sci. and Techno. (accepted), 2017.

30. GHONEIM A.M., AL-ZAHRANI S.S., EL-MAGHRABY S.E., AL-FARRAJ A.S. Heavy metal distribution in Fagonia indica and Cenchrus ciliaris native vegetation plant species. J. of Food, Agriculture \& Environment, 12, 320, 2014.

31. CHIBUIKE G.U., OBIORA, S.C. Heavy Metal Polluted Soils: Effect on plants and bioremediation methods. Applied and Enviro. Soil Sci. 1155, 2014.

32. CHEN X.W., TSZ-FUNG, WONG J., MO W.Y., MAN Y.B., WANG-WAI N.G., WONG M.H. Ecological Performance of the Restored South East New Territories (SENT) Landfill in Hong Kong (2000-2012). Land Degrad. Development, $1,1,2015$.

33. OLIVEIRA M.L.S., MAROSTEGA F., TAFFAREL S.R., SAIKIA B.K., WAANDERS F.B., DABOIT K., BARUAH B.P., SILVA L.F.O. Nano-mineralogical investigation of coal and fly ashes from coal-based captive power plant (India): an introduction of occupational health hazards. Sci Total Environ. 468, 1128, 2014.

34. SAFFARI M., KARIMIAN N., RONAGHI A., YASREBI J., GHASEMI-FASAEI R. Stabilization of nickel in a contaminated calcareous soil amended with low-cost amendments. J. of Soil Science and Plant Nutrition, 15, 896, 2015.

35. WANG H.Q., ZHAO Q., ZENG D.H., HU Y.L., YU Z.Y. Remediation of a magnesium-contaminated soil by chemical amendments and leaching. Land Degrad. Development. 26, 613, 2015.

36. ROY M., MCDONALD L.M. Metal uptake in plants and health risk assessments in metal-contaminated smelter soils. Land Degrad. Development, 26, 785, 2015.

37. ZHAO Z., JIANG G., MAO R. Effects of particle sizes of rock phosphate on immobilizing heavy metals in lead zinc mine soils. J. Soil Sci. Plant Nutr. 14, 258, 2014.

38. MOLLAHOSEINI H. Long term effects of municipal wastewater irrigation on some properties of a semiarid region soil of Iran. Inter. J. of Engineering and Technology, 4, 444, 2014. 